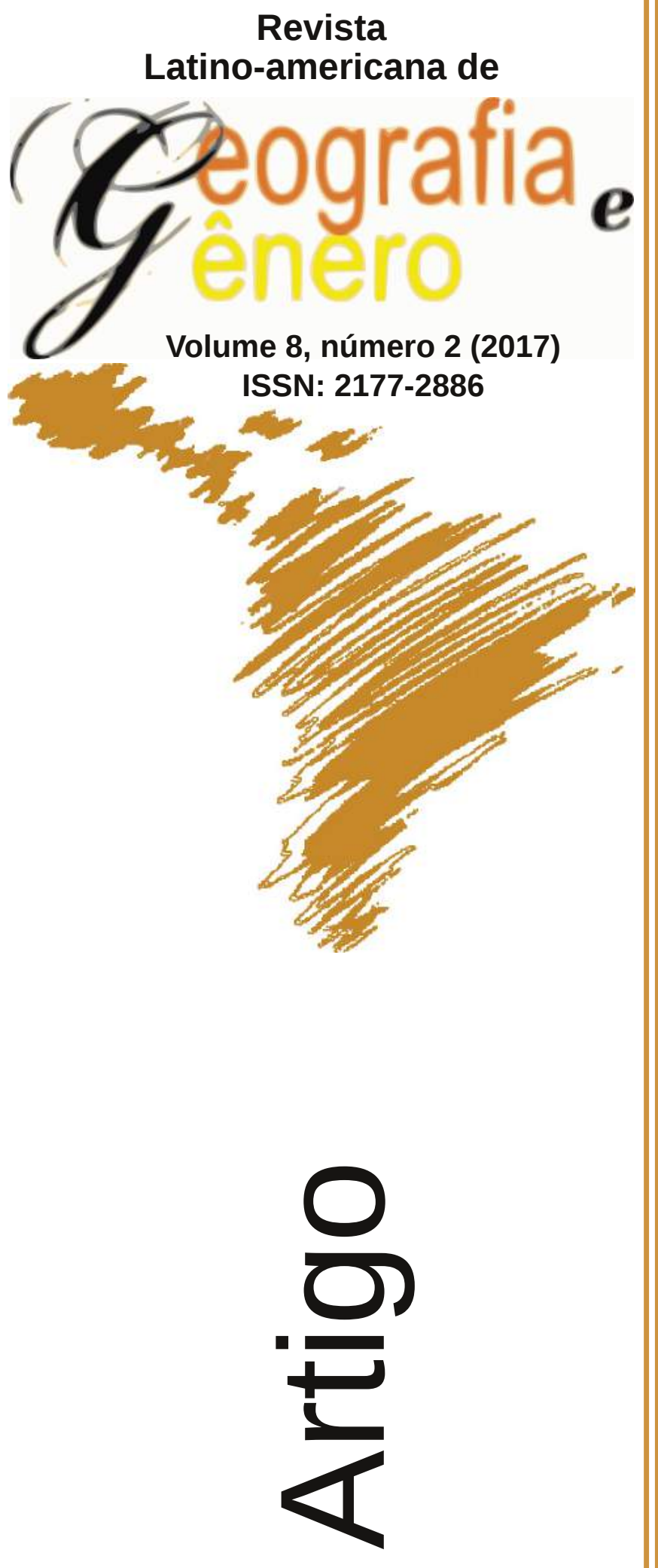

'Quase Tudo sobre Minha Mãe':

a Figura Materna entre Memórias e Narrativas

'Casi todo sobre mi madre': la Figura Materna entre Memorias y Narrativas

'Almost Everything about my Mother': the Mother Figure between Memories and Narratives

Georgiane Garabely Heil Vázquez

Universidade Estadual de Ponta Grossa - Brasil profgeorgiane@hotmail.com

Como citar este artigo:

VÁZQUEZ, Georgiane Garabely Heil. "Quase Tudo Sobre Minha Mãe": A Figura Materna entre Memórias e Narrativas. Revista Latino Americana de Geografia e Gênero, v. 8, n. 2, p. 207-223, 2017. ISSN 2177-2886.

Disponível em:

http://www.revistas2.uepg.br/index.php/rlagg 


\title{
'Quase Tudo sobre Minha Mãe': a Figura Materna entre Memórias e Narrativas
}

\author{
'Casi todo sobre mi madre': la Figura Materna entre Memorias y Narrativas
}

\author{
'Almost Everything about my Mother': the Mother Figure between Memories \\ and Narratives
}

\begin{abstract}
Resumo
Procurou-se debater sobre as reconstruções narrativas vinculadas à figura materna, a partir de entrevista com três gerações de mulheres. O primeiro grupo, ou primeira geração, nasceu nas décadas de 1920/1930. O segundo grupo é formado por mulheres nascidas nas décadas de 1940/1950. Já o terceiro grupo é composto por mulheres nascidas nas décadas de 1960/1970. Cabe destacar que as entrevistas foram realizadas com mulheres que não tinham filhos e tiveram, como eixo de análise, a figura das mães das entrevistadas. O debate se ampara em termos teóricos nas discussões sobre estudos de gênero, bem como nas reflexões sobre as ressignificações da memória de mulheres. Por meio da análise das entrevistas foi possível verificar as diferentes idealizações acerca da maternidade e as memórias femininas sobre suas próprias mães.
\end{abstract}

Palavras-Chave: Maternidade; Mulheres; Sentimentos; Memória.

\section{Resumen}

Se buscó debatir sobre las reconstrucciones narrativas vinculadas a la figura materna a partir de entrevistas con tres generaciones de mujeres. El primer grupo, o primera generación, nació en las décadas de 1920/1930. El segundo grupo está formado por mujeres nacidas en las décadas de 1940/1950. El tercer grupo está compuesto por mujeres nacidas en las décadas de 1960/1970. Cabe destacar que las entrevistas fueron realizadas con mujeres que no tenían hijos y tuvieron como eje de análisis la figura de las madres de las entrevistadas. El debate se ampara en términos teóricos en las discusiones sobre estudios de género, así como en las reflexiones sobre las resignaciones de la memoria de las mujeres. Por medio del análisis de las entrevistas fue posible verificar las diferentes idealizaciones acerca de la maternidad y las memorias femeninas sobre sus propias madres.

Palabras-Clave: Maternidad; Mujeres; Sentimientos; Memoria.

\section{Abstract}

This paper discusses narrative reconstructions of the mother figure, based on an interview with three generations of women. The first group, or first generation, was born in the decades of 1920/1930. The second group is formed by women born in the decades of 1940/1950. The third group is composed of women born in the 1960s and 1970s. It should be noted that the interviews were conducted with childless women, so the analysis focused on the figures of the interviewees' mothers. The debate is theoretically based on the discussions from gender studies, as well as on reflections about the re-significance of women's memory. Through the analysis of the interviews, it was possible to verify different idealizations about motherhood, which reflected the female memories about their own mothers.

Keywords: Motherhood; Women; Feelings; Memory. 


\section{Notas Preliminares}

Refletir sobre o amor materno é uma tarefa complexa. Primeiro, por se tratar de um sentimento que está inscrito no terreno das emoções e das sensibilidades, e, em segundo lugar, mas não menos importante, por evocar a memória a respeito do sentimento que nossas mães nos dispensaram ao longo da vida. Esse é um terreno pantanoso que mistura fantasias e experiências lembradas. Inquietações no estilo "fui amada por minha mãe?" acabam por surgir quando se constata que o amor, assim como todos os demais sentimentos humanos, é inconstante, variável, incerto (PRIORE, 2006; ROUGEMONT, 2003).

Este artigo visa problematizar como mulheres que nunca tiveram filhos, e, portanto, não são mães, reconstroem por meio das teias da memória, suas experiências de infância com suas mães e, portanto, a partir de entrevistas, problematizar as narrativas sobre as figuras maternas apresentadas. A opção por direcionar a entrevista para a memória da infância foi estabelecida por ser este o momento da vida de maior contato, inclusive físico, com a figura materna ${ }^{1}$. Narrar sua própria relação com a mãe foi feito sempre, nas dezessete entrevistas que realizei, de forma intensa e com sentimentos contraditórios. A mãe é apresentada como heroína, figura amorosa, ou, então, em outro polo, sem muitos contornos, distante dos filhos, quase que um ser não amoroso e não relacional. Em ambos os campos narrativos, existe intensidade emocional, muitas vezes lembranças carregadas de fortes emoções.

$\mathrm{O}$ que se procura problematizar neste artigo é o amor materno como um fenômeno cultural e não como um instinto cravado na 'natureza humana', ou mesmo algum tipo de virtude de seres biologicamente nascidos e categorizados como 'mulher' (BUTLER, 2000).

Ao propor uma análise sobre o sentimento do amor materno, me alinho a um segmento historiográfico que visa questionar a supremacia da racionalidade como única forma de explicar o mundo social e mesmo o político. Essa historiografia, iniciada no princípio do século XX com o movimento dos Annales, tem uma guinada rumo às questões que abarcam os sentimentos após a chamada 'virada linguística' dos anos de 1970 e as propostas desconstrutivistas.

Assim, acredito que problematizar historicamente os sentimentos e seu papel nas sociabilidades, nas subjetividades e mesmo nas ações sociais individuais e coletivas, seja relevante, tendo em vista que em nenhuma cultura os sujeitos agiram, propuseram ou silenciaram por uma determinação que não tivesse a ver com suas aspirações, temores, ódios, apegos, simpatias e amores.

Sentimentos são entendidos, aqui, como experiências e percepções que se ligam à dimensão afetiva e sensível da experiência humana. Eles participam da vida social, definindo identificações, estabelecendo ou rompendo vínculos sociais, criando ou negando afinidades. Dessa forma, os debates sobre a construção social a respeito do amor, bem como a exaltação desse sentimento

1 É evidente que nem todas as pessoas e nem mesmo todas as entrevistadas tiveram esse contato próximo, contudo partiu-se do ideal socialmente construído acerca do que se espera da maternidade. 
na configuração subjetiva das mulheres e, em especial, daquelas que não foram mães, serão destacados.

Lembrar da mãe e reconstruir uma memória narrativa sobre quem foi essa mulher foi tarefa carregada de sentimentos para minhas entrevistadas, até porque, para o ideal de maternidade construído historicamente, a mãe deve seguir um padrão de candura, mesclado com a boa severidade (BADINTER, 1985). Contudo, nem sempre as mães foram narradas dessa forma.

Ao refletir sobre a maneira como as mães de minhas entrevistadas foram narradas, utilizo as considerações de Sarlo (2007), pois, faz significativas considerações sobre a memória como um bem comum e a respeito do discurso narrativo que é emitido a partir dela. Quando Sarlo trabalhou com testemunhos de crimes cometidos nas ditaduras, argumentou que existe um núcleo de verdade inquestionável nos fatos narrados, mas, o discurso de seus narradores não estava protegido por essa ideia de núcleo inquestionável. Da mesma forma, compreendo que minhas entrevistadas, ao construírem estratégias narrativas a respeito de suas mães, suas relações e sentimentos, estão, em essência, produzindo discursos. Sabe-se que os discursos, por mais verdadeiros que se pretendam, são narrativas permeadas de singularidades, de lacunas e de reconstruções a partir da memória acionada no momento da entrevista.

Existe, portanto, uma diferença significativa entre o processo histórico e a narração em si. Para pontuar essa diferença, Sarlo (2007) recorre às reflexões de Paul Ricoeur sobre o presente como o momento da narrativa. Assim, o presente é o tempo dos discursos enunciados sobre o passado e, assim, o momento presente do entrevistado interfere diretamente em sua narração sobre o passado. ${ }^{2}$ Existe, consequentemente, a marca do presente ao se narrar o passado. Dessa forma, as experiências e os sentimentos narrados no momento da entrevista dependem intrinsecamente da condição efetiva da vida da pessoa que lembra nesse momento.

Para Sarlo, existe uma espécie de 'utopia do relato', pois, a possibilidade de recuperar detalhes, "reviver" sentimentos e narrar com precisão algumas passagens, pode levar à ilusão de que o concreto sobre a experiência passada foi "capturado" pelo discurso no momento da entrevista.

Defendo que narrar-se é, em seu cerne, reconstruir-se. As mulheres que entrevistei, por diversas vezes, "me entrevistavam" também. Respondiam perguntas e ao mesmo tempo me perguntavam sobre como era minha experiência de maternidade, como eram as lembranças sobre minha mãe. Por inúmeros momentos, senti que algumas delas queriam ouvir o que eu pensava sobre a maternidade, sobre ser mãe ou mesmo sobre não ser mãe.

As narrativas que as mulheres entrevistadas forneceram foram construídas a partir de jogos e negociações sutis. As lembranças que acessaram serviram

2 Esse foi o fator definidor para que esta pesquisa não abordasse mulheres em situação asilar. A possibilidade de entrevistar mulheres sem filhos que vivem em abrigos até foi considerada no início da pesquisa, mas, se tais entrevistas fossem realizadas abriria um novo campo, para além das gerações de mulheres que me propus entrevistar, ou seja, o campo das memórias de pessoas asiladas. Entrevistar mulheres asiladas implicaria em tratar de abandono, de laços familiares rompidos. Considerei que, nesse momento, deveria tratar apenas das mulheres sem filhos que convivem com familiares, que trabalham e que lembraram de suas mães para além das paredes de um asilo. 
para a construção discursiva de uma imagem sobre si mesmas e de suas famílias, mais especificamente, de suas mães.

Candau (2014), em diálogo com Ricoeur, acredita que existe uma reprodução ininterrupta de lembranças que estão em reconfiguração permanente. Para Candau, a memória fornece uma espécie de 'conservação de si' ao longo do tempo, e suas articulações e interdição de esquecimentos são fatores centrais na configuração de nossas subjetividades. Sem a memória, o 'sujeito' é aniquilado. Porém, a memória não fornece o passado em si, mas reconfigurações narrativas sobre o passado.

De acordo com Candau (2014), pensar o tempo significa classificá-lo, ordená-lo, denominá-lo e datá-lo. Ao separar as mulheres entrevistadas por grupos geracionais, procurei estabelecer algum critério de ordenação temporal. Todavia, ainda segundo Candau, a memória ignora a cronologia rigorosa da história, as datas precisas que balizam contextos, e o fluxo do tempo não possui o mesmo rigor quando acessado pelas teias complexas das lembranças.

As entrevistadas das três gerações formularam narrativas sobre o passado que fluíam entre o presente no qual vivem e a ressignificação dos processos históricos que viveram. Suas subjetividades e experiências foram narradas e reconfiguradas a partir da licença que obtive para partilhar de seu 'tempo privado', ou seja, de suas intimidades e das lembranças escolhidas sobre suas mães. Algumas me concederam maior espaço, narraram momentos íntimos, tristes e alegres. Outras, com maior reserva, responderam com mais formalidade, muitas vezes silenciando ou dando respostas rápidas e imprecisas. Suas histórias, sentimentos e vivências com suas mães foram as inquietações centrais dessa pesquisa ${ }^{3}$ e que tratarei doravante.

\section{Sobre a Mãe que Tive e seu Amor}

Neste tópico, selecionei algumas das entrevistas que 'narram mães' vinculadas ao ideal de afetividade, amor. Foi assim a entrevista realizada com Salvina, nascida no ano de 1960, em Manaus, AM, mas que vive há oito anos na cidade de Ponta Grossa, PR. Devido à difícil situação econômica enfrentada, Salvina não pode ir para a Universidade quando jovem e somente agora, na casa dos 50 anos, é que ingressou no Ensino Superior. Assim, a entrevista com ela foi realizada em uma pequena sala reservada na biblioteca de uma das faculdades particulares da cidade de Ponta Grossa, PR. Embora, por vezes, durante a entrevista pudéssemos perceber alguns olhares curiosos de outros alunos ou de funcionários, Salvina chorou como se estivesse sozinha em seu quarto, rodeada das lembranças reconstituídas naquele momento da entrevista.

Com as emoções despertadas pela memória, ela iniciou sua história tentando recompor parte da infância e, também, dos valores e vivências familiares no Amazonas, ao longo dos anos de 1960 e início dos de 1970. Quando perguntei “como a senhora descreveria seus pais?”, ela iniciou:

Eu fui muito amada pela minha mãe, ela que me defendia. Já pelo

3 Por solicitação das entrevistadas todos os seus nomes foram alterados. 
meu pai... pelas condições dele de lá [Amazonas] não podia me dar o que era preciso... porque quando minha mãe casou ela já estava grávida da minha irmã e logo em seguida ela engravidou de novo [gestação de Salvina]. E aí ele pediu até pra minha mãe abortar e minha mãe disse que fez tudo pra abortar, mas eu fui tão teimosa que nasci (Salvina-terceira geração). ${ }^{4}$

É interessante notar como sua narrativa se constrói por antinomia, iniciando pelo amor materno, que, paradoxalmente, está associado pelas tentativas maternas de aborto e por sua 'teimosia' em nascer. Salvina não se abalou ao falar sobre a tentativa de aborto que a própria mãe admitiu ter realizado, mas se emocionou ao falar do amor, do zelo da mãe em oposição ao abandono afetivo que, na concepção dela, era realizado pelo pai. É como se a frase "fui muito amada pela minha mãe" servisse como justificativa para a tentativa de aborto e, também, compensasse, em alguma medida, o desamor do pai que ela narrou em seguida:

Eu fui crescendo e meu pai me dizia que eu não era filha dele, que eu me afastasse dele, que eu fui muito rejeitada por ele. Daí, minha mãe tinha que dar uma explicação pra mim. Por que tanta rejeição... daí ela contou isso [tentativa de aborto a pedido do marido, pois tinham uma filha ainda pequena]. Acho que eu tinha 8 pra 9 anos. A questão é que eu atrapalhei, eu vim pra atrapalhar... talvez os projetos dele... eu tive muita raiva, não só dele como da minha vó, que era mãe dele, até uns 17 ou 18 anos, eu tive muita raiva. Por quê? Era assim... ele chegava com os presentes em casa quando a gente era criança e tinha certinho 4 brinquedos, então não tinha brinquedo pra mim ${ }^{5}$ (Salvina - terceira geração). ${ }^{6}$

Em oposição ao pai que desprezava, Salvina, em suas memórias, construiu uma mãe que amava e esse amor a confortava. As mães são estereotipadas, tanto quanto as mulheres que não possuem filhos. Porém, esses estereótipos são articulados em campos discursivos diferentes. A mãe, que socialmente é reconhecida como "digna de tal título", é estereotipada positivamente. É a mulher protetora, que ampara e ama. A mãe suporta tudo, as dores pelos filhos, os dissabores conjugais, tudo por amor à prole. É essa linguagem do mito que estabelece um discurso universalizante sobre a mãe e a maternidade. Daí o dito popular de que todas as mães são iguais.

Em contraponto, a mãe que se desvia do caminho preestabelecido pelo mito, as mães que expressam desinteresse, desamor e que até chegam a matar seus filhos, são retiradas da história de suas vidas e colocadas no campo estéril da patologia, sendo caracterizadas como monstros cruéis (VÁZQUEZ, 2014).

Forna (1999) salienta que a existência de estereótipos referentes às mães, e

4 Entrevista concedida em 04 de maio de 2013.

5 Salvina teve, ao todo, quatro irmãos. Ela foi a segunda filha de um total de cinco.

6 Entrevista concedida em 04 de maio de 2013. 
ao modelo de mãe que a sociedade espera das mulheres, extrapola o ato de parir e maternar. Ações como doar a vida, ou parte da vida, em função da prole são bem vistas para a classificação da mulher como 'boa mãe'.

As lágrimas de Salvina se intensificavam na medida em que ela narrava a coragem materna de enfrentar o pai, de lutar pelo bem-estar dela e de seus irmãos. Em nenhum momento ela considerou que a maternidade é modelada pela cultura e que pode ser flexível, pois, em um primeiro momento, a mãe de Salvina aceitou a ideia do aborto, e até por volta de seus 8 anos não se manifestava contrária aos abusos de autoridade do pai, especialmente o desprezo dele por Salvina. Somente após alguns anos vivendo nessa situação é que a mãe decidiu optar pelos filhos, em especial por Salvina, e romper com o casamento:

Pra compensar minha mãe trazia brinquedo pra mim... a minha relação com minha mãe não é de filha e mãe... é de irmã. Hoje eu tenho 53 e minha mãe tem 67/68 anos. Depois que minha mãe se separou, a minha mãe ficou sendo o pai da família e eu sendo a mãe, assumi esse papel até as meninas [irmãs] casarem, dai depois eu assumi os sobrinhos... e assim vai... ${ }^{7}$ (Salvina- terceira geração). ${ }^{8}$

Por ser uma das filhas mais velhas, Salvina acompanhou o processo de separação da mãe, e tal vivência acabou por reforçar a figura da mãe como heroína:

A mais velha não era filha dele. Ele casou com minha mãe grávida de 8 meses, mas o filho não era dele, e ele sabia. Ele casou pra amparar minha mãe. Ele era apaixonado por ela. O que matou mesmo foi a familia dele. Imagine aceitar que um homem case com uma mulher grávida de outro. A mais velha foi aceita por ele. O que era mais frustrante pra minha mãe foi isso. Parece alguma coisa de espiritismo, porque só eu fui rejeitada... e a filha que não era dele foi aceita... ninguém entende. Minha mãe se separou... ela fugiu com a gente. Ele era muito violento, quando batia no meu irmão, deixava meu irmão de cama. Eu enfrentava ele desde criança... nós fomos pra outro bairro, bem distante, um bairro em Manaus que nem existia no mapa... ficamos isolados lá. Saímos de um lugar que a gente tinha luxo, empregada... pra um lugar de chão batido, paredes de tecido, tipo choupana e o telhado era de palha. Dai minha mãe saía pra trabalhar e deixava eu com os menores e de lá a gente foi se virando. Ela foi conseguindo empregos melhores... minha mãe foi muito batalhadora. Ela criou a gente tudinho sem a gente ser influenciado por nada e nunca fez a gente ter ódio do pai... Depois ela conheceu o pai das meninas [segundo casamento]. Eu tinha uns 17 anos e minha mãe foi morar em Belém do Pará, eu fiquei com os irmãos. Desse

7 Entrevista concedida em 04 de maio de 2013.

8 Salvina teve, ao todo, quatro irmãos. Ela foi a segunda filha de um total de cinco. 
segundo casamento ela teve duas filhas, uma que nasceu em Belém e outra que nasceu em Manaus, porque eles voltaram. Do meu pai nós só tivemos notícias há uns 10 anos atrás, porque minha cunhada trabalhava no hospital e viu um homem muito parecido com meu irmão, o Júnior, dai falou pra nós... estava em coma, sem documento, quando chegaram lá pra ver... era meu pai. Daí minha mãe foi pra lá, deu amparo pra ele e dai uns 8 meses ele morreu. Demos cuidado, custeamos fraldas, tudo pra ele, até o enterro. A minha mãe nunca deixou ter ódio dele, ela justificava que talvez fosse a criação dele, o jeito dele... ele morreu nos braços da minha mãe, meu padrasto ficou " $p$ da vida"! Mas, foi ele que amparou minha mãe quando ela estava grávida, sozinha... sem abrigo, vagando. Meu pai era uma pessoa muito boa só que o problema deles era a bebida e o ciúme dele. No fundo eu gostava dele, mas ele nunca conseguiu se aproximar de mim (Salvina- terceira geração). ${ }^{9}$

Ao narrar as experiências de sua mãe, Salvina recompõe um ideal de maternidade, tanto que na reconstrução da morte do pai sua mãe é descrita como uma Pietà, abrigando-o nos seus braços no momento derradeiro. O pai, apresentado como distante, austero e violento, é narrado como o contraponto da mãe, que sofreria calada, aguardando um momento para se libertar. Ao longo da entrevista, ficou evidente como Salvina constrói uma imagem materna de coragem e ternura. Em todas as entrevistas, sentimentos como admiração, amor e respeito foram uma constante na reconstrução das memórias acerca da figura materna. Contudo, Araújo e Moura (2004) destacam que tal elaboração discursiva compõe parte das condições de maternagem e das características que o amor materno assumiu no período contemporâneo. Nesse sentido, a construção do papel da mulher no cuidado com os filhos incorreu na seguinte relação: tornou-se tanto mais exclusivo quanto menor se tornava a determinação biológica para a maternidade. Assim, quanto menos filhos as mulheres gestavam, mais exclusivos deveriam ser seus cuidados para com eles. Tal fato seria parte de uma configuração social específica, na qual a mãe deve ser o exemplo a ser seguido e sobre ela não deve haver mácula alguma.

Autores como Chodorow (1990), por meio da análise crítica dessa redefinição contemporânea da maternidade, acabaram por criar um conceito, "a mãe moral", ou seja, a infalível:

[...] o período capitalista inicial produziu uma ideologia da 'mãe moral': as mulheres burguesas deviam agir ao mesmo tempo como educadoras e modelos morais para seus filhos, assim como alimentadoras e guias morais para seus maridos na sua volta do mundo de trabalho imoral e competitivo (CHODOROW, 1990, p. 19).

Nesse sentido, o ideal da 'mãe moral' foi representado pelas atitudes da mãe de Salvina, que, durante alguns anos, procurou compreender as atitudes agressivas do marido para com os filhos. Salvina narra que viviam em uma

9 Entrevista concedida em 04 de maio de 2013. 
casa com luxo, com empregada doméstica e que, frequentemente, seus irmãos ganhavam brinquedos, ou seja, pertenciam a uma camada beneficiada economicamente no Amazonas do período dos anos de 1960 e início da década de 1970. Todavia, a configuração específica de violência, e mesmo a austeridade com os filhos, fez com que a mãe rompesse com o casamento, fugindo do marido.

A 'mãe moral' descrita por Chodorow (1990), deveria ser uma espécie de guia para o marido, que, endurecido pelas lides do trabalho e do mundo de competitividade, deveria encontrar nela o refúgio e o norte para agir corretamente com a família. Todavia, na família de Salvina, a mãe não obteve sucesso em 'guiar' as atitudes paternas e, assim, a solução encontrada para manter o ideal de boa mãe foi abandonar o luxo, a empregada, o marido. A mãe de Salvina fugiu com os filhos, foi trabalhar fora e os deixava sozinhos enquanto trabalhava, usando o velho esquema das famílias pobres nas quais as filhas mais velhas cuidavam dos irmãos mais novos.

Tal atitude materna poderia, a priori, soar como um rompimento com os modelos estabelecidos para a 'boa maternidade', pois a mãe de Salvina rompeu com os laços conjugais. No entanto, ocorreu justamente o reforço da concepção de 'mãe moral', na medida em que esse rompimento foi justificado como a única forma de livrar os filhos do sofrimento. Ela fugiu do marido por amor aos filhos, na narrativa de Salvina. Ao mencionar que o pai comprava brinquedos para os outros e não para ela, e também que o pai espancava seu irmão a ponto de deixá-lo de cama, Salvina, automaticamente, justifica a atitude da mãe e reforça a ideia de 'mãe heroína', que se submete ao trabalho, suporta as adversidades morando numa casa de chão batido para criar os filhos longe da violência do marido. Outro aspecto importante a ressaltar em sua narrativa é como ela mantém o arranjo familiar, dizendo que sua mãe assumiu metaforicamente o lugar do pai, indo trabalhar, e ela o lugar da mãe, cuidando dos irmãos mais novos enquanto sua mãe trabalhava.

Outro exemplo no qual a bondade e o heroísmo da mãe aparecem em oposição à rudeza do pai é a narrativa de Regiane, nascida em 1974, na localidade de Barra do Encontro, na zona rural do município paranaense de Reserva.

Ao aceitar conceder entrevista, Regiane fez apenas uma ressalva: "eu falo, mas você tem que esperar eu terminar o serviço. Não consigo pensar e trabalhar" (Regiane- terceira geração). ${ }^{10}$ Após um dia trabalhando como diarista, ela se sentou ao meu lado à mesa e iniciou sua narrativa onde o desejo de filho ainda é uma constante. Ela quer ter um filho, ela ainda pode ter um filho pelos modos tradicionais, sua menstruação ainda vem e ela tem um namorado, mas, não aceita a hipótese de engravidar sem estar casada, e não pode casar porque além das lides como diarista, ela é a filha que ficou responsável pelo pai que está doente, há anos na cama, requerendo constantes cuidados.

Ao rememorar sua vida e recompor com as significações da atualidade, Regiane, assim como Salvina, constrói a figura da mãe heroína. O pai, que hoje necessita dela para comer, tomar banho e todas as demais atividades

10 Entrevista concedida em 01 de junho de 2013. 
corriqueiras da vida, é apresentado com certa distância emocional e ressentimento. O pai severo e a mãe bondosa são os principais personagens na construção narrativa elaborada por Regiane:

O pai sempre foi uma pessoa rígida, não deixava a gente sair. Você ia pra escola, se passasse de 5 minutos [do horário estipulado para a volta] você levava uma surra. Agora por causa disso hoje ele tá pagando, porque o pai não foi fácil. O pai era ruim pra mãe... às vezes ela não podia nem trabalhar na roça porque tava doente, mas tinha que ir trabalhar porque senão o pau quebrava. As vezes ele ameaçava de bater nela... bater a gente nunca via ele bater, né... mas... ele judiava da mãe. A mãe incentivava a estudar, o pai não. Ele dizia assim "pra que estudar, pra ser burro?", eu tenho vergonha de falar que tenho só até a $4^{a}$ série, minha filha, o que é a $4^{a}$ serie, não é nada. Eu, minha filha, não tive gosto de brincar de boneca. Quando ganhei uma boneca eu tinha 14 anos, que era da minha irmã. Porque quando eu queria, que era criança, eles não compravam porque não tinham dinheiro. Desde os meus 8 anos eu cuidava da casa. Lavava, passava e cozinhava... lavava até roupa, não tive o gosto de brincar. Porque eu tinha dó da mãe... porque ela ficava o dia inteiro trabalhando na roça e daí chegar em casa e ter tudo pra fazer. Eu ficava em casa e eu fazia o que eu vencia fazer... porque tinha dó da mãe (Regiane- terceira geração). ${ }^{11}$

A figura da mãe é narrada de forma quase 'mítica' e, nessa narrativa, o amor materno ganha uma retribuição, o amor filial. Regiane busca transmitir a ideia de que todo o seu esforço em assumir os cuidados com a casa, e até abrir mão de sonhos infantis, como o fato de não ganhar uma boneca, se justificam em prol de algo maior, em nome da mãe.

É a devoção à mãe que faz Regiane narrar sua infância em função dela. Quando narrou que a mãe era obrigada a trabalhar na roça, mesmo doente, seus olhos lacrimejaram. A memória de uma mãe, hoje já falecida, compôs um ideal de maternidade que se articulava perfeitamente com o sofrimento, com a dedicação e com o enfrentamento da pobreza e da rudeza do marido para conseguir criar os filhos. Uma mãe que, apesar da violência paterna, conseguiu criar os filhos e uma filha, a qual, apesar de ter sofrido pela rudeza do pai, hoje cuida dele, ou seja, mãe e filha estão unidas pelo dever e pela resignação.

Nada pode ser obstáculo ao amor das mães, nem maridos violentos, nem companheiros irresponsáveis. Badinter (1985) aborda não apenas a construção da ideia de amor materno e instinto materno, mas, também, a construção desse modelo de mãe (a nova mãe). Para a autora, esse vínculo que na atualidade nos é apresentado como atemporal e irrefutável, teve sua historicidade vinculada aos discursos insistentes e repetitivos, proferidos desde a época de Rousseau por moralistas, romancistas e médicos. Todavia, a incorporação desses discursos pelas mulheres foi um processo paulatino e inconstante que perpassou os séculos XIX e XX.

11 Entrevista concedida em 01 de junho de 2013. 
As 'provas de amor' maternais se iniciam com as práticas de aleitamento e se estendem para o fato de que "[...] o bebê e a criança transformam-se nos objetos privilegiados da atenção materna. A mulher aceita sacrificar-se para que seu filho viva, e viva melhor, junto dela" (BADINTER, 1985, p. 202).

Dessa forma, a sobrevivência e todo o futuro do bebê/criança passaram a depender, exclusivamente, dos cuidados maternos e, em maior ou menor grau, encontramos tal ideia presente nas entrevistas. Segundo Nancy Chodorow (1990), a ideia de um vínculo 'único e insubstituível' com a mãe é uma construção histórica. Em outros tempos e sociedades, as crianças eram criadas por diversas pessoas e, nem por isso, apresentavam um desenvolvimento inferior ao esperado socialmente delas. Dessa forma, não se pode traçar uma regra geral para o que vem a ser 'uma boa maternagem', sendo que tal prática sociocultural decorre de contextos específicos.

Aproximando discursivamente as narrativas e provas de amor materno cobradas por diferentes discursos e mesmo pelo senso comum com os relatos das entrevistas, o que se nota é a reiteração da representação de 'boa mãe'. Ernestina, nascida em 1934, na localidade de Tereza Cristina, interior do município de Candido de Abreu, PR, usa poucas palavras para descrever a relação com os pais, em especial com a mãe. Via de regra, as entrevistadas com mais idade, implicadas aqui no que denominei como a primeira geração de mulheres, falaram bem menos do que as entrevistadas mais jovens. Respostas curtas e objetivas, porém, ricas em significados e representações. Nesse caso, Ernestina relata da seguinte forma a relação que tinha com seus genitores:

Eram os melhores pais do mundo. O meu pai faleceu com 76 anos, era resmungão bastante. A mãe era uma santa, faleceu com 60 anos... caiu morta, deve ter sido coração. Brincavam um pouco... e trabalhava em tudo, na roça, cuidava da casa. Eu ajudava a mãe... (Ernestina - primeira geração). ${ }^{12}$

Embora Ernestina diga que ambos eram os melhores pais do mundo, descreve o pai como resmungão, ou seja, de certa forma ela deixa claro que algo lhe incomodava no pai. $\mathrm{O}$ adjetivo resmungão pode ter vários significados, que vão desde a extrema exigência com tarefas cotidianas até mesmo à insatisfação com a família. A mãe, descrita como uma santa, solicitava seus auxílios nas lides da casa e da roça, e ela a ajudava de bom grado. Durante a entrevista, Ernestina, em momento algum, demonstrou tristeza por ter que ajudar os pais na lavoura e se privar de brincadeiras e mesmo do estudo. A vida era assim e ajudar a mãe era o esperado de uma boa filha, numa relação na qual se misturam poder, amor e obediência.

Essa imagem idealizada da mãe está presente nas entrevistas realizadas com as mulheres das três gerações. Ernestina, representante da primeira geração, descreve a mãe como santa. No extremo oposto em termos de idade, Carolina, uma representante da terceira geração de mulheres aqui apresentada, ao se referir à mãe e à complexa relação que teve com ela, a descreve da seguinte

12 Entrevista concedida em 03 de junho de 2013. 
forma:

Meus pais eram extremamente preocupados. Dedicados e superprotetores. Embora eu tivesse vivido uma infância com muitos conflitos entre o casal [entre o pai e a mãe]. Minha mãe é viúva faz 3 anos. Minha mãe sobrevivia, não era infeliz nem totalmente feliz... essa é a lembrança dela [...]. A psicóloga falou que eu tenho medo da maternidade porque o exemplo de mãe que eu tenho é a minha mãe... porque ela é uma mãe heroína e sempre passou uma imagem que ser mãe é sofrer (Carolina - terceira geração). ${ }^{13}$

Carolina narra uma pequena parte de sua infância e, ao fazê-lo, lembra da relação com a mãe. Ao longo da entrevista, a figura de sua mãe é retomada várias vezes, é a mãe que inicia uma empreitada comercial com ela, é a mãe que lhe ajudou quando sofreu um aborto natural, é a mãe que, mesmo em conflito com o pai, suportou o casamento até a morte do companheiro.

Retomando as ideias apontadas anteriormente neste tópico, a mãe heroína é narrada aqui novamente em sua plenitude, inclusive sendo nomeada assim pela entrevistada. Carolina não chega a culpar a mãe pelo seu 'medo de maternidade', mas, ao afirmar que a figura da mãe sempre lhe pareceu forte e sofredora, acaba por dizer que existe dentro de si uma espécie de 'medo' da maternidade, pois, não sabe se conseguiria ser 'tão forte' ou tão resignada quanto a mãe foi ao longo da vida.

Nesse sentido, aqui se estabelecem todas as representações sociais vinculadas à ideia de boa mãe. Mesmo tendo problemas conjugais desde o início do casamento, a mãe de Carolina optou por manter essa relação. Os motivos podem ser os mais variados. Não temos como saber, pois Carolina não chegou a mencioná-los com certeza, pois nunca conversou com a mãe sobre isso, apenas diz que mesmo com os conflitos a mãe não se separou e, hoje, na condição de viúva, pode-se dizer que 'cumpriu' o dever traçado socialmente para ela, pois manteve o casamento até a morte do marido. Seja pelos filhos, seja por condições financeiras, ou mesmo por dependência emocional, o fato é que essa mulher, chamada por Carolina de 'mãe heroína', representava a força e o amor que ela admirava, levando a pensar na contra face dessa representação, a mãe sacrificial, tão solidamente enraizada em nossa cultura.

Ao mencionar o fato de que sua mãe passou a imagem da mãe sofredora, ela reforça a ideia da 'mãe heroína', ou seja, aquela que sofre, que se sacrifica e que, muitas vezes, permanece calada para conseguir um benefício, não para si, mas para os filhos, ou, então, para a família. O sofrimento e o sacrifício são a condição para o engrandecimento do ato heroico da maternidade construída socialmente.

Ser mãe, para Carolina, era ser como sua mãe foi. Ela, todavia, já havia passado por separações, já havia passado por um aborto natural e, em diversos momentos da vida adulta, precisou recorrer à mãe, da mesma forma como o fez na infância. Carolina considerou que não seria forte o suficiente, heroína o suficiente e nem queria ser sofredora o suficiente, como foi sua mãe. A recusa

13 Entrevista concedida em 08 de maio de 2013. 
ou o medo da maternidade expressam sua dúvida ou mesmo sua negação de não conseguir ser como sua mãe foi, de não conseguir suportar todas as coisas que ela suportou.

Aqui, percebi que existem diferentes formas de resistências sutis ao modelo de maternidade hegemônico traçado e disseminado na contemporaneidade. $\mathrm{O}$ medo de maternidade que Carolina menciona pode ser entendido como uma tensão, uma discordância em relação ao modelo de mãe que lhe foi apresentado. Quando ela diz "ela é uma mãe heroína e sempre passou a ideia de que ser mãe é sofrer", está demonstrando que abre mão do "heroísmo" vinculado à maternidade, ela não quer sofrer e tem o direito de, assim, querer. De certa forma, Carolina percebeu que o ideal de felicidade articulado com a figura de 'mãe heroína' é, praticamente, impossível de ser atingido em suas condições de vida. Ela desejou ter filhos, tentou engravidar recorrendo até aos saberes médicos, mas, ao final da entrevista concluiu que era feliz e não precisou de um filho para isso.

As mulheres que, de alguma forma, não se encaixavam nos modelos preestabelecidos para a figura da boa mãe, da 'mãe heroína', ou, então, aquelas que não levaram a cabo a experiência de cuidar de seus filhos, também fazem parte do que poderíamos chamar de 'história da maternidade', ou, então, 'história do amor materno'. É certo que elas não figuram entre as representantes mais gloriosas da função de mãe e, muitas vezes, foram descritas como pessoas frias, severas, cruéis ou, simplesmente, atarefadas demais para a maternidade. Mas, como ressalta Badinter (2011), a experiência da maternidade não é sempre igual e, tampouco, desejada por todas as mulheres em qualquer momento da vida. Para a autora, antes da década de 1970, os filhos eram compreendidos como uma espécie de consequência natural de um casamento. Dessa forma, as mulheres casadas, e em condições de engravidar, o faziam sem muitas perguntas ou reflexões. Essa consequência natural do casamento foi tão pouco debatida que em muitas áreas, como em segmentos da Psicologia, ainda é possível encontrar ecos do discurso universalista sobre a maternidade. Ao tratar dos conflitos e ambivalências da maternidade, Badinter (2011) analisou um dossiê da revista Psychologies Magazine, publicado em maio de 2009. Nesse documento de ampla circulação no meio de acadêmicos da área de Psicologia, em diversos países, a filósofa francesa encontrou a afirmação: "o desejo de ter filhos é universal. Ele nasce das profundezas do cérebro [...] do motivo por que somos feitos: prolongar a espécie" (BADINTER, 2011, p. 17).

Contestando a concepção de que existe um instinto e um desejo universal por filhos, Elisabeth Badinter argumenta que esse desejo não é constante, pois, existem múltiplas situações afetivas e de vida material que interferem na decisão de ter filhos, ou mesmo de manter uma gestação. Dessa forma, existe a escolha e não um desejo universal inflexível.

A escolha por ter filhos, pressupõe algum grau de reflexão e de opção. Tais questões, ao contrário do que se disseminou no senso comum, não estão estritamente relacionadas com o amor incondicional da mãe, mas sim com um complexo segmento de desejos e deveres que Badinter (2011) procurou mapear.

Nesse sentido, compreendo que seja necessário debater justamente o outro 
lado da maternidade. Um lado pouco estudado e que nos leva a refletir sobre a noção histórica de imperfeição dos sentimentos humanos. Mães, como todas as outras pessoas, são seres humanos e, embora as narrativas possam apresentálas como santas, plenamente amadas pelos filhos e bondosas, elas também possuem 'defeitos'. Aqui, tratarei daquilo que a sociedade ao longo do século $\mathrm{XX}$ acabou por classificar como a pior distorção vinculada às mulheres, $\mathrm{o}$ desamor ou o desinteresse pelos filhos.

Em detrimento à toda a campanha levada por diferentes discursos, dentre eles o religioso, o médico e até mesmo o pedagógico, algumas mulheres simplesmente não se sentiam realizadas com a maternidade (FORNA, 1999), ou, então, suas filhas não conseguiam enxergar nelas as figuras heroicas que acreditavam poder sempre encontrar em uma mãe.

Badinter (1985) fala sobre as distorções entre o mito da maternidade e a realidade ou a vida cotidiana da maioria das mulheres. Para a autora, desde a publicação de 'O segundo Sexo', por Simone de Beauvoir, em 1949, e, mais especificamente, a partir dos feminismos da década de 1960, surgiram novos discursos feministas que tiveram por finalidade central questionar o mito freudiano da "mulher normal" e junto a ele "[...] as teorias da mãe naturalmente devotadas, nascidas para o sacrifício" (BADINTER, 1985, p. 332). Assim, teorias consagradas dentro da psicanálise, como a fundamental importância das distinções entre os papéis paterno e materno para o bom desenvolvimento da criança, também foram questionadas.

Junto a esses questionamentos de ordem teórico-política, Badinter (1985) apregoa que o papel destinado à mãe, longamente construído e cultivado desde meados do século XVIII, também ruiu para boa parte das mulheres. Quando busquei, nas entrevistas com mulheres não-mães, narrativas que tratam do desamor ou da severidade materna, não encontrei muitos relatos relevantes. Via de regra, as mães são apresentadas como dóceis ou sofredoras. São apresentadas como mulheres nas mãos de um homem (o pai), que as machucam constantemente. Todavia, algumas poucas entrevistas mencionam o distanciamento que pode existir entre a mãe e suas crianças. Esse é o caso da entrevista de Maria Luiza, nascida em 1941, na cidade de Prudentópolis, PR.

Ela foi abandonada pela família biológica e adotada por uma família da cidade de Reserva, PR, ainda quando era bebê. Quando questionada sobre a mãe biológica, simplesmente disse: "não sei nada dela e nem quero saber" (Maria Luiza - segunda geração). ${ }^{14}$ Mesmo quando falou sobre a mãe adotiva, embora sempre demonstrasse gratidão, mencionou a rigidez com que foi criada. Maria Luiza também faz o contraponto entre a mãe e o pai, todavia, para ela, o pai é narrado como o "porto seguro" e o que demonstrava mais amor.

Meus pais não eram muitos severos... meu pai nunca surrou os filhos. A mãe um pouco mais severa... toda vida o pai era calmo, tranquilo. A mãe era mais brava... Agora, a mãe tem que ser brava mesmo, né. Ela tem que tomar as rédeas... (Maria Luiza - segunda geração). ${ }^{15}$

14 Entrevista concedida em 08 de maio de 2013.

15 Entrevista concedida em 02 de junho de 2013. 
Um ponto importante que foi observado nas entrevistas é que quando a figura da mãe das entrevistadas não se articula com a representação de 'mãe heroína' ou de 'mãe sofredora', os relatos eram extremamente breves. Essa constatação também pode ser observada na entrevista de Maria Luiza, que descreve o pai como tranquilo, calmo, e menciona o fato de ele nunca ter batido nos filhos. Quando a questionei se a mãe costumava bater, ela apenas sorriu timidamente, não respondeu à pergunta de forma direta. Apenas reiterou aquilo que já havia falado, "a mãe era brava".

Quando abordou memórias maternas, Ana Paula Vosne Martins (2005) constatou que mulheres mais idosas não narravam seus partos e suas experiências com a maternidade com sentimentos intensos. Ao contrário, a autora percebeu que, para as mais velhas, a maternidade significava 'trabalho'. Também, as mães das mulheres entrevistadas pela autora foram lembradas de maneira distante, como alguém a quem deviam respeito, mas não devoção. Para Martins, as mulheres que nasceram antes de 1930 e, portanto, tiveram suas experiências de maternidade em meados das décadas de 1940 e 1950 (como é o caso da mãe adotiva de Maria Luiza), a propaganda a respeito de um modelo ideal de maternidade ainda não estava plenamente consolidada.

Nesta pesquisa, também verifiquei que as entrevistadas mais jovens narram suas mães como heroínas, como sofredoras e lutadoras, porém, as de mais idade apenas descrevem rapidamente a severidade e o distanciamento da mãe, construindo discursivamente suas mães, quase que exclusivamente, como 'trabalhadoras' na lavoura ou nos serviços domésticos.

Poucas palavras para descrever sentimentos confusos e conflitantes, sentimentos que abarcam a gratidão e que, ao mesmo tempo, demonstram a dificuldade em lidar com a severidade ou a indiferença materna.

Retomando a entrevista de Maria Luiza, percebi que ela justifica tal severidade com a afirmação de que a mãe deveria ter as rédeas da casa em suas mãos, ou seja, caberia à mãe controlar os filhos com o intuito de educá-los. A severidade pedagógica como necessária às mães faz parte de um amplo conjunto de imagens não romantizadas sobre a maternidade, que, assim como o amor materno, passaram a ser divulgadas em meados do século XVIII e, sem estabelecer linha reta, acabaram chegando para as diversas sociedades dos séculos XX e XXI.

\section{Considerações Finais}

O papel da mãe obtém um sentido maior, tornando-se um sujeito passível de valor a ser cultivado, ensinado, domesticado, na medida em que a criança passa a ser vista como um indivíduo inocente, vulnerável e merecedor de cuidados específicos.

A mãe passa a ser a disciplinadora, pedagoga por excelência, é ela quem deve produzir esse futuro cidadão que está sobre seus cuidados maternais. Para tal ação pedagógica, muitas vezes se fazia necessário o uso da força corretora ou da severidade, mas a sociedade caracterizou essa atitude materna não como 'violência', e sim como ensinamento, amor necessário, embora algumas vezes exercido com força. 
Dessa forma, a ausência de amor ou a severidade ao amar não são entendidos da mesma forma ao se avaliar o comportamento. A ausência de amor materno é descrita como inadequação e sugere algo de errado com a personalidade da própria mãe. Nesse sentido, frases como "ela não ama os filhos porque é imatura", ou, então, "ela não ama os filhos porque é narcisista", compõem discursos sobre a maternidade, que visam combater qualquer tipo de 'desvio' do que deveria ser o sentimento maternal. Em contrapartida, a 'severidade ao amar' é narrada pelas entrevistadas, sendo reconstruída como algo inerente a esse tipo de amor. Ser severa era algo, também, esperado da mãe moldada a partir do século XVIII. Ser severa e demonstrar essa severidade, muitas vezes com constrangimento físico e palavras duras, fazia parte dos atributos da mãe preocupada com o futuro dos filhos, que eram, também, potenciais 'cidadãos de bem', tudo dependendo da forma como ela os criava.

Contudo, Badinter (1985; 2011), assim como Forna (1999), destacam que o que deveria aparecer com maior destaque dentro desse modelo de maternidade era a construção da mãe heroína e, como verificado nas entrevistas, esse modelo de mãe foi amplamente encontrado.

Todavia, dialogando com as pesquisas de Martins (2005), este estudo ressalta que, para as mulheres mais idosas, ou seja, nas entrevistas com mulheres da primeira e segunda geração, a figura materna foi narrada com maior distanciamento. Maternar é um ato cultural, vivenciado de diferentes formas ao longo dos tempos. Assim, a heroína, abdicada e sofredora em prol dos filhos está muito mais relacionada com as mães narradas pelas mulheres da terceira geração, mulheres que nasceram nos anos de 1960 e 1970.

Pela análise de minhas entrevistas, concluo que, foi a partir da segunda metade do século XX, numa articulação de saberes e deveres, que a maternidade ganhou os ares que conhecemos na atualidade. Historicizar o amor materno, eis aí um campo ainda por desbravar na historiografia brasileira.

\section{Referências}

ARIÉS, Phillippe. História Social da Criança e da Família. Rio de Janeiro: LTC, 1981.

BADINTER, Elisabeth. Um amor conquistado: o Mito do Amor Materno. Rio de Janeiro: Nova Fronteira, 1985.

BADINTER, Elisabeth. O Conflito: a mulher e a mãe. Rio de Janeiro: Record, 2011.

BAUMAN, Zygmunt. Amor Líquido. Sobre a fragilidade dos laços humanos. Rio de Janeiro: Zahar, 2009.

BUTLER, Judith. Cuerpos que importam: sobre los limites materiales y discursivos del "sexo". Buenos Aires: Paídos, 2002.

BUTLER, Judith. Corpos que pesam: sobre os limites discursivos do sexo. In: 
LOURO, Guacira L. O corpo educado: pedagogia da sexualidade. 2ed. Belo Horizonte: Autentica, 2000, p. 110 - 127.

CANDAU, Joel. Memória e Identidade. São Paulo: Contexto, 2014.

CHODOROW, Nancy. Psicanálise da Maternidade. Uma Crítica a Freud a Partir da Mulher. Rio de Janeiro: Rosa dos Tempos, 1990.

DEL PRIORE, Mary. História do Cotidiano. São Paulo: Contexto, 2000.

DEL PRIORE, Mary. (Org) História das Mulheres no Brasil. São Paulo: Contexto, 1997.

DEL PRIORE, Mary. História do Amor no Brasil. São Paulo: Contexto, 2006.

FORNA, Aminatta. Mãe de todos os mitos: como a sociedade modela e reprime as mães. Rio de Janeiro: Ediouro, 1999.

MARTINS, Ana Paula Vosne. Memórias maternas: experiências da maternidade na transição do parto doméstico para o parto hospitalar. História Oral, v. 8, p. 61 - 76, 2005.

MOURO, Solange Maria S. Rolin; ARAÚJO, Maria de Fátima. A maternidade na história e a história dos cuidados maternos. Revista Psicologia: ciência e profissão, n. 24, p. 44 - 55, 2004.

POLLAK, Michael. Memória, Esquecimento, Silêncio. Estudos Históricos, v 2, n. 3, p. $3-15,1989$.

POLLAK, Michael. Memória e Identidade. Estudos Históricos, v.5, n. 10, 200 - 215, 1992.

RICOEUR, Paul. A memória, a história, o esquecimento. Trad. Alain Fraçois. Campinas: Ed. Unicamp, 2006.

ROUGEMONT, Denis de. História do Amor no Ocidente. 2 ed. São Paulo: Ediouro, 2003.

SAFER, Jeanne. Além da maternidade. Optando por uma vida sem filhos. São Paulo: Mandarim, 1997.

SARLO, Beatriz. Tempo Passado: cultura da memória e guinada subjetiva. São Paulo: Companhia das Letras, 1997.

VAZQUEZ, Georgiane Garabely Heil. Mais cruéis do que as próprias feras? Aborto e infanticídio nos Campos Gerais/ PR entre os séculos XIX e XX. Curitiba: Universo do Livro, 2014.

Recebido em 11 de maio de 2017.

Aceito em 03 de novembro de 2017. 